\title{
In Search for New Realities in Post-Pandemic Dystopia
}

\author{
Tereza Turzíková
}

\begin{abstract}
Střed zájmu: Kultura v nové realitě [Focal Point: Culture in the New Reality]. Multidisciplinary conference. Organized by Institut umění - Divadelní ústav [Arts and Theatre Institute] and Kancelář Kreativní Evropa [Creative Europe]. November 23, 2020. Online.
\end{abstract}

The year 2020 has shaken the foundations of our society and provoked a search for new ways to structure and organise public and private institutions as well as our personal lives. The online conference Focal Point invited a number of cultural representatives, ranging from arts practitioners and curators to theorists and journalists, and asked them the crucial question: What is going to be the role of culture in the new reality?

\section{Transformation of society: Everything needs to change}

The opening section, focused on environmental crisis in relation to social mechanisms and contemporary economic systems, provided a scientific perspective and solid basis for further discussion. In their talk, the natural scientists and environmental activists Jan Hollan and Yvonna Gaillyová posed climate change as the most pressing issue of today and suggested specific steps to take in order not to stop global warming, but to decelerate it to a sustainable level. Without deep structural and economic changes implemented on a global scale, lowering an individual's carbon footprint could be nothing but a futile gesture. The gravity of the situation might be illustrated by the words of Frans Timmermans (Vice President of the European Commission) cited by Hollan and Gaillyová: Everything needs to change for things to remain the same.

Relationality of contemporary crises was highlighted by economist-environmentalist Nad'a Johanisová, who sees environmental and economic crises, the COVID-19 pandemic, and systemic inequality as interrelated symptoms of late-stage capitalism. In such a system, the status quo is justified by the ideology of infinite economic growth, as criticized by the following speaker, economist and journalist Jan Bittner. Bittner pointed out that contemporary society considers GDP as the most reliable parameter of social well-being, while the pandemic clearly proved otherwise. Public health has become more important than economic stability, and the governmental restrictions led to the so-called Matthew effect: enrichment of the rich and impoverishment of the poor in a time of crisis.

The role of culture in such times might be crucial, as Anna Kárníková (director of the environmental NGO Hnutí DUHA) suggested before stressing the necessity to create positive utopias and new imaginations. The consequences of the pandemic, as of any other crisis, will fully unravel over time, and culture might help with the 
exploration of the newly emerging futures and value systems. From a philosophical point of view offered by Alice Koubová, culture can be something that establishes facts, and therefore wields power and responsibility, despite being often regarded as non-essential. Furthermore, Koubová proposed conceptual re-thinking of artistic and cultural practices, so that art would not be dependant on an online environment nor on the currently restricted unmediated social contact.

\section{An Audit of culture: Fighting the grantosis virus}

The two thematically linked pre-recorded contributions by Luigi Sacco (Professor of Cultural Economics in Milan) and David Korecký (manager and curator of the Rudolfinum Gallery, Prague) both advocated for seeing the crisis and uncertainty as accelerators of a social change that might lead to radical innovations in technology and arts. Experimentation and openmindedness might generate new forms of interactions and relationships and potentially re-define the position of cultural institutions in our daily lives.

A refreshing perspective was offered by the choreographer Yemi A.D., who is familiar with both domestic and foreign scenes, as well as main-stream production (e.g. collaboration with Kanye West) and artistic practice. He sees the situation caused by the pandemic as a double-edged sword: in dance, it is impossible to mediate the physical contact and the hic et nunc feedback loop via online streaming, however, it may also be a way to reach a wider audience from different layers of society. Following the topic of bringing culture to audiences during lockdowns, Jan Press as the director of the Moravian Gallery in Brno pondered the possibilities of the digitalization of art and events that typically take place in gallery spaces. While hosting an online conference might not seem difficult, transforming the entire exhibiting practice of art poses a challenge. Nevertheless, Press noted, the carbon footprint that is left behind each exhibition would be, in the digitalized practice, almost nonexistent.

Film director Vít Janeček (Film and TV School of the Academy of Performing Arts in Prague) provided a cinematographer's perspective resulting in a critical analysis of the issues of consuming culture exclusively via a computer screen, which obliterates the distinction between everyday life and cultural events. Explaining how the structure of the film industry in the Czech Republic differs from other arts in its institutional network, he reflected on the potential stagnation of film production due to COVID-19 and on the return of filmmakers to cinematic experimentation and small forms.

In the concluding debate, art critic Anežka Bartlová brought up the term grantosis (grantóza) which applies to contemporary reality of artists relying on deadline-based grants as the main source of their income. This negatively affects not only the artists and their work but also devalues art itself by reducing it to a market logic. Ivan Buraj, theatre director (HaDivadlo, Brno) critically observed the market-based mechanisms present in the theatre and proposed to review the criteria for evaluating culture, with a view to replacing those of revenues and audience turnout. Furthermore, he pointed to Germany as an example of a country that 
produces high-quality art thanks to stateguaranteed economic support for people employed in cultural spheres, with a hope that the Czech government might one day provide a similar safety net.

\section{Artists' perspective: An Infrastructure of Care}

The final block consisting of various artists was the one most saturated with the personal day-to-day experience of contemporary crisis and highlighted the interconnectedness of the personal with the political. As Apolena Rychlíková pointed out, not only does she have to pursue her occupation as a journalist and documentary filmmaker while being a mother, in the newly emerged situation, she also had to become a tutor. It becomes apparent that care is the infrastructure of survival in today society, and hopefully the pandemic might become an impulse for structural change vital to social well-being. A similar point was made by Adam Borzič (poet and translator), who believes in abolishing the pressure of productivity and establishing a right for relaxation instead. He also pointed out the dual nature of contemporary reality: while being horrendous, it is also inspirational, and while we are in isolation, the isolation is what creates a bond between us.

Noemi Purkrábková, an art theorist and journalist, elaborated on the concept of online proximity established by the impossibility of physical contact. This forced digitalization of art that we have undergone has revealed the dysfunctions in artistic practice that might serve as a motive for innovation. According to Purkrábková, the artistic field that dealt with digitalization most creatively turned out to be the alternative music scene due to its inclination towards the audiovisual and digitally performative form. Furthermore, choreographer and dance director Miřenka Čechová shared her experience of the shift in contemporary dance - the work becomes more narrative and less physical, which she perceives as a significant degradation of the entire field. For Čechová personally, the current situation has brought some positive impulses as well: she perceives a certain level of unpredictability as inspirational, as long it does not become an imminent existential threat.

At one point in the final discussion, Apolena Rychlíková voiced a notion that I personally find very significant and relatable in today's reality: our desire, or even capability, to consume cultural practice online is decreasing as we are forced to do the majority of our daily tasks in front of the screen. The oversaturation of the ability to perceive content is related to the diminishing distinction of everyday responsibilities and what should be a cultural event. In the online environment, cognitive perception is rid of bodily experience and relies solely on intellectual ability and concentration.

The conference raised a number of valuable questions and provided an in-depth analysis of multiple phenomena of today while also demonstrating the weaknesses of online conferences. Though they may provoke intellectually, they lack the joy of physical presence, a sense of togetherness in a social event. 
